\title{
The origin of the uranium - molybdenum deposit Kurišková
}

\author{
Mikuláš Fekete \\ Masaryk University, Faculty of Science; Kotlářská 267/2, 61137 Brno, Czech Republik; e-mail: sekretariat@sci.muni.cz \\ (c) 2015 Authors. This is an open access publication, which can be used, distributed and reproduced in any medium according \\ to the Creative Commons CC-BY 4.0 License requiring that the original work has been properly cited.
}

The contents of my presentation are based on my bachelor thesis, which was aimed at the genesis of the U-Mo deposit Kurišková. The thesis was written by a form of research, where the existing opinions of the deposit genesis, its characteristics and mineralization were summed up, and the mineral resources were estimated.

The deposit is situated in Eastern Slovakia, roughly $7 \mathrm{~km}$ WNW from the outskirts of Košice, about 600 meters above sea level. It was discovered in 1985 by a state owned company Česko-slovenský uránový prieskum and was analyzed by a method of core drilling. In total, 53 drill cores were extracted. In 1996 the exploration works ceased. From 2005-2011 the research was renewed by Tournigan, Ltd. to study the mineralized zones further (Krajewski et al. 2011).

Geologically the uranium deposit Kurišková belongs to the metamorphic rocks of the Gemeric unit, a part of the Western Carpathian region, the rocks are strongly metamorphosed and fractured (Krajewski et al. 2011). The rock complexes are of the Permian age, characterized by a cyclical sedimentation of conglomerates, sandstones, siltstones and schists, with carbonates and anhydrite. There are also layers of volcanic rocks, such as porphyry and tuffs. (Pluskal 1971) These rocks are of intermediate, basic and also acidic composition (Krajewski et al. 2011). The bottom of the deposit is built by the Knola Formation which consists of effusive - sedimentary rocks of continental, continental - lagoon and lagoon nature (Andrusov
1983). Hanging wall is formed by Petrova Hora Formation, composed of intermediary, fine-grained porphyritic volcanic rocks. The mineralization of Kurišková deposit is concentrated in three zones (upper main zone, high grade main zone north, main zone south) and in a form of hangingwall mineralization, concentrated in andesites, andesite tuffs and meta-sediments. It is represented mainly by coffinite and uraninite (notably localized along the margins of small apatite stringers), along with a smaller amount of brannerite and orthobrannerite. The mineralization itself is thought to be the result of mobilization and resedimentation of uranium in the fault systems in this deposit during the Variscan and early Alpine orogenesis. Although the research of this deposit is not yet finished to enunciate a definitive opinion on its genesis, it is assumed that Kurišková is both epigenetic vein deposit and a deposit with disseminated character of mineralization. Its primary origins could be of sedimentary or volcano-sedimentary character. The source of uranium here is probably a process of devitrification of the tuff material, or the erosion of the granitic bodies in this area (Rojkovič 1990).

In the discussion part of my thesis I compared the Kurišková deposit to the Gurvanbulag deposit in Mongolia and with the deposits of the Bohemian Massif.

Gurvanbulag is a monometallic deposit in Mongolia. Its basement rocks are Proterozoic and composed of amphibolites, schists, gneisses with 
Paleozoic intrusions of gabbrodiorites, diorites and granites, the overlying volcanic rocks are Mesozoic (early Jurassic to early Cretaceus). The uranium mineralization is represented by coffinite, pitchblende and uranophane (Armstrong et al. 2009).

The uranium deposits of the Czech Massif, that are of a similar lithology and age are bound mainly to organic matter and coal. On the other hand, the lacustrine sediments that fill up the paleodepressions, along with subsequent volcanism create particularly good conditions for uranium mineralization (Arapov 1984).

Although there were no finds associated with organic material or coal on the Kurišková deposit, the underlying Knola Formation has a continental origin, covered with volcano-sedimentary Petrova Hora Formation, so in my opinion, the deposit is of a similar nature as the deposits mentioned by Arapov. On the other hand, Gurvanbulag deposit is different, based on the geological setting, the source of the uranium is the felsic volcanic pile and the basement rocks, according to Chabiron et al. 2003 (in Armstrong et al. 2009).

\section{REFERENCES}

Andrusov D., Began A., Biely, Borza K., Buday T., Bystrický J., Bystrická H., Cicha I., Eliáš M., Eliášová H., Fusán O., Gašpariková V., Gross P., Hanzlíková E., Köhler E., Houša V., Lehotayová R., Leško B., Ložek V., Menčík E., Michalík J., Mock R., Pesl V., Pícha F., Roth Z., Salaj J., Samuel O., Seneš J., Slávik J., Straník Z., Špička V., Vašíček Z., Vaškovský I. \& Vozár J., 1983. Stratigrafický slovník Západných Karpát. 1 A/K. Geologický ústav Dionýza Štúra, Bratislava.

Arapov J.A., Bojcov V.J., Česnokov N. I., Djakonov A.V., Halbrštát J., Jakovjenko A. M., Kolek M., Komínek J., Kozyrev V.N., Kremčukov G.A., Lažanský M., Milovanov I.A., Nový V. \& Šorf F., 1984. Československá ložiska uranu. Československý uranový průmys, Praha.

Armstrong T., Puritch E., Yassa A., Ewert W., Buck M., Malloch K., Steed C., Botham L., Rogers J. \& Fielder B., 2009. Technical Report and Feasibility Study on the Gurvanbulag Uranium Deposit Saddle Hills Property Dornod Province, Mongolia [pdf]. [on-line:] http://www.wise-uranium.org/uoasi.html\#GURVANBULAG.

Krajewski S.A., Rozelle J.W. \& Spiller E., 2011. Mineral Resource Update Kuriskova Uranium Project East-Central Slovakia [pdf]. [on-line:] http://www.tournigan.com/i/ pdf/Kuriskova_NI-43-101_Update_June_2011.pdf.

Pluskal O., 1971. Úvod do geologie uranových ložisek. Státní pedagogické nakladatelství, Praha.

Rojkovič I., 1990. Ore bearing Permian volcanism in the Western Carpathians. Acta Geologica Et Geographica Universitatis Comenianae. Geologica, 45, 71-88. 